\title{
OPTIMAL DESIGN OF INDUSTRIAL REACTOR FOR NAPHTHA THERMAL CRACKING PROCESS
}

\author{
Aysar Talib Jarullah', Arkan Jasim Hadi ${ }^{2}$, Shymaa Ali Hameed ${ }^{3}$ \\ 1, 2,3 Lecturer, Chemical Engineering Department, College of Engineering, Tikrit University \\ Email: a.t.jarullah@tu.edu.iq ${ }^{1,3}$, arkan.hadi@tu.edu.iq ${ }^{2}$
} (Received: 22/5/2014; Accepted: 14/12/2014)

\begin{abstract}
The ethylene production is regarded one of the most significant issues for chemical industries and improving its production operation can bring several benefits. Thus, the market demand for ethylene production has accelerated the improvement of a more rigorous and reliable thermal cracking model of such process. In the present study, developing a rigorous mathematical model for an industrial naphtha cracker is investigated based on experimental data combining with a kinetic model describes the coke formation on the internal reactor tubes.

The best kinetic model obtained is applied for predicting the products yield, the gas temperature and the optimal temperature profiles along the reactor to maximize the profit of the process. The influence of process factors on the optimal solutions (mainly, coil outlet temperature $(\mathrm{COT})$, steam to naphtha ratio $(\mathrm{S} / \mathrm{N})$ and feed flow rate on the product yields have also been discussed here, and new results of the reactor with the optimal cost and temperature profile are obtained.

Modeling, simulation and optimal design via optimization of the industrial thermal cracking reactor has been carried out by gPROMS software. The optimization problems are solved employing a Successive Quadratic Programming (SQP) method formulated as a Non-Linear Programming (NLP) problem.
\end{abstract}

Keywords: Thermal cracking, Ethylene production, Naphtha pyrolysis, Ethylene furnace.

\section{INTRODUCTION}

Recently, the worldwide ethylene production increases rapidly (approximates 180 billion $\mathrm{lb} / \mathrm{yr}$ ), and its annual industrial production depends on the thermal cracking of oil hydrocarbons (mainly naphtha) with steam, where the heart of the ethylene unit with a massive economic effect is the furnace of the cracking process ${ }^{(1,2)}$. The main parameter of the optimal design of such reactor is the accurate prediction of yield and reactor performance. Coil outlet temperature (COT), steam to hydrocarbon ratio $(\mathrm{S} / \mathrm{N})$ and feed flow rate play a 
significant factors affecting ethylene yield ${ }^{(3,4)}$. Control systems are designed for achieving several goals, involving product quality, safety, and minimum cost. Many operations can be employed in ethylene production in spite of the process, which is favored in modern practice includes the cracking reactions ${ }^{(2)}$.

Naphtha feedstock will be mixed with operation steam then both are introduced into a reactor (which is cracking coil) at high temperatures. For increasing the selectivity of the olefin and reducing the coke formation, steam is utilized for this purpose via decreasing the partial pressure of hydrocarbon. The paraffinic compound will be cracked thermally into namely olefins, aromatics, $\mathrm{CH}_{4}$ and $\mathrm{H}_{2}$. Owing to the endothermic behavior of the homogeneous cracking reactions, the reactions are requiring energy inlet to get gas temperatures at the coil output within the range of $800-900^{\circ} \mathrm{C}$, which can be obtained by a thermal cracking furnace. The furnace of the process will impact the entire operation leading to disturbance because the first stage in olefin production process is the furnaces. As mentioned above, the coil outlet temperature (COT) has a significant influence upon the yield of ethylene production and thus it should be controlled, where the temperature of the cracked gas measures at the coil output and then manipulating the heat inlet to the furnace. This behavior plays an important role loop to control the thermal cracking reactors ${ }^{(1,2,4)}$.

It is noticed that the temperature profile inside the reactor has also an important impacts upon the product yield as well as the coke formation. An increase in the temperature, the ethylene and propylene yield will increase beside the rate of coke deposition (more details of the coke formation mechanism can be found in Kopinke et al. ${ }^{(5,6)}$. In order to obtain the maximum yield of a desired olefin and to reduce the expenses owing to reactor shutdown as a result of decoking, an optimum temperature profile along the reactor should be achieved ${ }^{(7)}$. In this study, a rigorous mathematical model of naphtha thermal cracking process to obtain the optimal design of such reactor is studied depending on experimental data obtained by a real industrial plant. The model presented with accounting the impacts of coke formation has been modified via optimization process to obtain the optimum kinetic parameter that can be applied with high confidence to reactor design. Secondly, the model is then applied to find the optimal operations, optimal temperature profile along the reactor, decreasing of production time as well as decoking cost based on the objective function, which is the maximum profit of the process within gPROMS package.

\section{INDUSTRIAL THERMAL CRAKING REACTOR UNIT}

The experimental data of the industrial thermal cracking reactor using a typical straight run naphtha feedstock have been supplied by the Arak Petrochemical Company $(\text { ARPC })^{(8)}$. The naphtha feedstock composition is presented in Table 1 . The furnace consists 
of 8 split reactor coils arranged as a staggered row. The basic information of the industrial naphtha cracking reactor and the configuration of the reactor is shown in Table $2^{(9)}$. Coil outlet temperature $(\mathrm{COT})$, steam to naphtha ratio $(\mathrm{S} / \mathrm{N})$ and feed flow rate are the main process conditions of the cracker resulting different product yields data (mainly ethylene), which will be utilized to obtain the best kinetic parameter via optimization process (in case 1). Following the parameter calculation, the model is extended for predicting the ethylene and propylene yields at different operating conditions outside the range of the data given that provides further insight of the operation.

\section{MATHEMATICAL MODEL OF THERMAL CRACKING REACTOR}

Mathematical model of naphtha thermal cracking reactor needs information related to the reaction behavior beside transport operations, namely mass, energy, and momentum transfer inside the reactor ${ }^{(7)}$. Naphtha is widely used as a feedstock substance for the furnaces of such process in most of the ethylene plants. Naphtha consists of a complex mixture of hydrocarbon substances within the range from propane $\left(\mathrm{C}_{5}\right)$ to decane $\left(\mathrm{C}_{10}\right)$ and its cracking includes many free-radical reactions. In the reactor, several cracking reactions can be occurred for producing ethylene and propylene ${ }^{(3,10)}$.

The cracking furnace is considered the heart of ethylene unit. To obtain an optimum operation strategy, it is important to investigating the effects of the operation variables that can be satisfactory evaluated through the rigorous modeling. Mathematical model of the cracking plant is divided into thermal section and chemical section. In the first section (thermal), the relations between the heat inlet to the furnace and the temperature profile along the reactor tube are studied. While, the cracking reactions and the concentration of the products at the reactor output related to the temperature and pressure profiles along the reactor tube are described in the second section ${ }^{(2)}$.

In this study, one-dimensional plug-flow reactor model is utilized for simulation the thermal cracking tubular reactor. A complete reaction network, employing a rigorous kinetic model for naphtha decomposition has improved and utilized to simulate the reactor of naphtha cracking process ${ }^{(11)}$. More details about the kinetic scheme utilized can be found by Towfighi and Nazari ${ }^{(12)}$, and Sundaram et al. ${ }^{(13)}$. The following assumptions are considered for the mathematical model: 1) one dimensional flow, 2) radial temperature variation is neglected, 3) plug flow and laminar flow regime, and 4) axial dispersion is negligible.

The prevailing mass, energy and momentum balance relations are as the following Mass balance equation (M.B):

$\frac{d F_{i}}{d z}=\alpha \sum_{j=1}^{N r} s_{i j} r_{j}=\frac{\pi d_{r}^{2}}{4} \sum_{j=1}^{N r} s_{i j} r_{j}$ 
Momentum balance equation (MO.B):

$\left(\frac{1}{M_{m} P_{T}}-\frac{P_{T}}{\varphi G^{2} R T_{g}}\right) \frac{d P_{T}}{d z}=\frac{d\left(1 / M_{m}\right)}{d z}+\frac{1}{M_{m}}\left(\frac{1}{T_{g}} \frac{d T_{g}}{d z}+F_{r}\right) \quad \Rightarrow$

$\frac{d P_{T}}{d z}=\frac{\frac{d\left(1 / M_{m}\right)}{d z}+\frac{1}{M_{m}}\left(\frac{1 d T_{g}}{T_{g} d z}+F_{r}\right)}{\left(\frac{1}{M_{m} P_{T}}-\frac{P_{T}}{\varphi G^{2} R T_{g}}\right)}$

$M_{m}=\sum_{i=1}^{N c} y_{i} M_{i}$

The friction factor can be estimated as follows ${ }^{(1,7)}$ :

$F_{r}=\frac{0.092}{R e^{0.2} d_{r}}$

For the straight portion of the tubes, there will be

$F_{r}=\frac{0.092}{R e^{0.2} d_{r}}+\frac{\delta}{\pi R_{b}}$

$\delta=\left(0.7+0.35 \times \frac{\forall}{90^{\circ}}\right)\left(0.051+0.19 \frac{d_{r}}{R e}\right)$

The bend angle $(\forall)$ is $180^{\circ}$ in the present study ${ }^{(7)}$.

Energy balance equation (E.B):

$$
\begin{aligned}
& \sum_{i=1}^{N c} F_{i} c p_{i} \frac{d T_{g}}{d z}=Q(z) \pi d_{r}+\frac{\pi d_{r}^{2}}{4} \sum_{j=1}^{N r} R_{j}\left(-\Delta H_{j}\right) \quad \Rightarrow \\
& \frac{d T_{g}}{d z}=\frac{\left(Q(z) \pi d_{r}+\frac{\pi d_{r}^{2}}{4} \sum_{j=1}^{N r} R_{j}\left(-\Delta H_{j}\right)\right.}{\left(\sum_{i=1}^{N c} F_{i} c p_{i}\right)}
\end{aligned}
$$

Giving the gas temperature profile in the reactor, the profile of heat flux along the reactor can be achieved via E.B correlation. The furnace wall temperature profile is got by back estimation. Radiation is assumed the dominant mechanism of heat-transfer from the furnace wall to the reactor. The heat-transfer rate can be given as follows ${ }^{(10)}$ :

$q=A_{w} \sigma\left(T_{F w^{-}}^{A} T_{w}^{A}\right)$

The heat-transfer coefficient in the tube can be estimated by the following equation ${ }^{(7)}$ :

$\frac{h d_{r}}{\lambda}=0.023 \operatorname{Re}^{0.8} \operatorname{Pr}^{0.4}$

The properties of the mixture like density, viscosity as well as thermal conductivity are estimated as the following ${ }^{(14,15)}$ :

$\rho_{m}=\sum_{i=1}^{N c} y_{i} \rho_{i}$

$\rho_{i}=\frac{P M_{i}}{Z_{i} R T}$

$Z_{i}=1+\frac{9}{129} \frac{\operatorname{Pr}}{\operatorname{Tr}}\left(1-\frac{6}{T r^{2}}\right)$

$\mu_{m}=\sum_{i=1}^{N c} y_{i} \mu_{i}$ 


$$
\begin{aligned}
& \mu_{i}=26.69 \times 10^{-7} \frac{\sqrt{M i T}}{0.654481 V c i \frac{2}{3} \omega} \\
& \omega=\left[1.16145 T_{*}^{-0.14874}\right]+0.52487\left[\operatorname{Exp}\left(-0.773201 T_{*}\right)\right]+2.16178\left[\operatorname{Exp}\left(-2.43787 T_{*}\right)\right] \\
& T_{*}=1.2593 T_{r i} \\
& \frac{1}{\lambda i}=\sum_{i=1}^{N c} \frac{y_{i}}{\lambda i} \\
& \lambda_{i}=4.0185 \times 10^{-23} \frac{\sqrt{M i T}}{V c i \frac{2}{3} \omega}
\end{aligned}
$$

Coke formation is regarded a complex phenomenon owing to the different possible coke forming reactions. The number of reactions is decreasing via restricting the number of coke precursors. Figure 1 illustrates the reactor tube cross section and as shown, 3 thermal resistances are found for thermal transport from the outer wall of the reactor to the gas in the tube of the reactor.

Paraffin is the main component in a naphtha feed stock. Aromatics compounds can be classified as a significant coke precursors and an aromatic ring form similar to the form of the coke template. As well as, the complex compounds of such materials are reactive compounds, particularly at elevated temperature predominant in thermal cracking reactors. The introduced model assumes that coke can be generated either from by ethylene, propylene, butadiene and aromatic as coke precursors. Coke models consist of the following parallel reactions as follows ${ }^{(16)}$ :

1) $\mathrm{C}_{2} \mathrm{H}_{4} \rightarrow$ Coke

2) $\mathrm{C}_{3} \mathrm{H}_{6} \rightarrow$ Coke

3) $\mathrm{C}_{4} \mathrm{H}_{6} \rightarrow$ Coke

4) $\mathrm{C}_{6} \mathrm{H}_{6} \rightarrow$ Coke

5) $\mathrm{C}_{7} \mathrm{H}_{8} \rightarrow$ Coke

6) $\mathrm{C}_{8} \mathrm{H}_{8} \rightarrow$ Coke

For each reaction, the following relation is written for the coking rate: $r c_{i}=C_{H_{2}} C_{H_{4}} k_{i} C_{i}$

The coke precursors can be divided into olefins, butadiene and aromatic ring based on their characteristic and the coking rate related to these groups are described as follow ${ }^{(5,6)}$ :

$$
\begin{aligned}
& r_{\text {Olefin }}=7.8589 \times 10^{8} \exp \left(\frac{-74.164}{R T}\right) \cdot\left(k_{c_{2 H_{4}}} C_{c_{2 H_{4}}}+k \quad C \quad c_{3 H_{6}} c_{3 H_{6}}\right. \\
& r_{\text {But }}=2.099 \times 10^{12} \exp \left(\frac{-127.94}{R T}\right) \cdot k_{c_{4 H_{6}}} C_{c_{4 H_{6}}} \\
& r_{\text {arom }}=4.1865 \times 10^{8} \exp \left(\frac{-29.977}{R T}\right) \cdot\left(k_{c_{8 H_{8}}} C_{c_{8 H_{8}}}+k_{c_{7 H_{8}}} C_{c_{7 H_{8}}}+k_{c_{6 H_{6}}} C_{c_{6 H_{6}}}\right)
\end{aligned}
$$


$r_{c_{\text {tot }}}=C_{H 2} C_{H 4}\left(r_{\text {Olefin }}+r_{\text {But }}+r_{\text {arom }}\right)$

\subsection{Objective Function Formulation}

Case 1: The minimization of the sum of the squared errors $(S S E)$ between the industrial data and calculated yields of ethylene and propylene components is employed as an objective function in the optimization process to estimate the best kinetic parameters. Non-linear regression is used to modify the chemical reaction rates (including the activation energy and the frequency factor for each reaction simultaneously) proposed by Pramod and Deepak ${ }^{(17)}$. The following relation is used for this purpose:

$S S E=\sum_{i=1}^{N c}\left(C_{i}^{\text {Ind }}-C_{i}^{e s t i}\right)^{2}$

Case 2: An increase in the COT, the ethylene yield and the coke deposition rate is increasing. Depending on these combined impacts, the optimum profile of the temperature along the reactor is achieved. The optimal kinetic parameters obtained from case 1 will be applied in case 2. Where, utilizing an objective function containing the appropriate maximum product yield in addition to the passive influence of coking rate, the profile of the gas temperature for thermal cracking of naphtha is reached to the optimum value and the maximum profit is obtained. In the present study, the following objective function for case 2 has been introduced

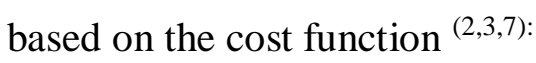

Objective function $=\operatorname{Profit}\left(f_{t}\right)=\operatorname{Income}\left(f_{1}\right)-\operatorname{Cost}\left(f_{2}\right)$

$f_{1}=\left(F_{C_{2} H_{4}} M_{C_{2} H_{4}} P_{C_{2} H_{4}}+F_{C_{3} H_{6}} M_{C_{6} H_{6}} P_{C_{3} H_{6}}\right) \cdot\left(t_{p}-n_{d e} \cdot t_{d}\right)$

$f_{2}=\left(F_{\text {naphtha }} M_{\text {naphtha }} P r_{\text {naphtha }}+F_{\text {steam }} M_{\text {steam }} P r_{\text {steam }}+Q_{H} P r_{H}\right) \times\left(n_{\text {de. }} . t_{d}\right)$

Decoking frequency depends on the average coke rate formed that will be as a function of the temperature behavior within the reactor. Giving a basic temperature, the decoking frequency as well as the average coking rate generation are expressed by $n_{d}$ as well as $r_{c o}$, hence their well be

$\frac{n_{d e}}{n_{d}}=\frac{r_{c t}}{r_{c o}}$

$r_{c t}=\frac{1}{L} \int_{0}^{L} r_{c_{t o t}}(z) d z$

Combining the last two equation gives

$n_{d e}=\frac{n d}{L r_{c o}} \int_{0}^{L} r_{c_{t o t}}(z) d z$

$n_{d}=\frac{t_{p}}{t_{e}+t_{d}}$ 
3.2 Optimization Problem Formulation of the Case Studies

The optimization problem for case 1 is described as follows:

Given

reactor configurations, operating conditions, process parameters

Optimize $\quad K_{j}, A_{j}$

So as to minimize the sum of squared errors

Subject to operation constraints and linear bounds on all control variables

Mathematically, the optimization problem for case 1 is stated as:

$$
\begin{array}{ccc}
\text { Min } & S S E & \\
K_{j}, A_{j} & & \\
\text { sub.to } & y(x, I(x), \underline{I}(x), g(x), q)=0, & \text { (model, equality constraints) } \\
& Y_{C 2 H}{ }^{L} \leq Y_{C 2 H} \leq Y_{C 2 H}{ }^{U} & \text { (inequality constraints) } \\
& Y_{C 3 H 6}{ }^{L} \leq Y_{C 3 H 6} \leq Y_{C 3 H 6}{ }^{U} & \text { (inequality constraints) } \\
K_{j}{ }^{L} \leq K_{j} \leq K_{j}{ }^{U} & \text { (inequality constraints) } \\
A_{j}{ }^{L} \leq A_{j} \leq A_{j}{ }^{U} & \text { (inequality constraints) }
\end{array}
$$

While, the optimization problem for case 2 can be stated as follows:

Given reactor configurations, operating conditions, process parameters

Optimize $\quad T_{C O T}, S / N, Q, t_{e}$

So as to maximize the operating profit of the process $\left(f_{t}\right)$.

Subject to operation constraints and linear bounds on all control variables

Mathematically, the optimization problem for case 2 is introduced as:

$$
\begin{array}{lll}
\text { Max } & f_{t} & \\
T_{C O T}, T_{W}, S / N, Q, t_{e} & \\
\text { sub.to } & y(x, I(x), I(x), g(x), q)=0, & \text { (model, equality constraints) } \\
T_{G}{ }^{L} \leq T_{G} \leq T_{G}{ }^{U} & \text { (inequality constraints) } \\
T_{C O T}{ }^{L} \leq T_{C O T} \leq T_{C O T}{ }^{U} & \text { (inequality constraints) } \\
Q^{L} \leq Q \leq Q^{U} & \text { (inequality constraints) } \\
S / N^{L} \leq S / N \leq S / N^{U} & \text { (inequality constraints) } \\
Y_{C 2 H 4} \leq Y_{C 2 H 4}{ }^{*} & \text { (equality constraints) } \\
Y_{C 3 H 6} \leq Y_{C 3 H 6}{ }^{*} & \text { (equality constraints) } \\
t_{e} \leq t_{e}{ }^{*} & \text { (equality constraints) }
\end{array}
$$


$y(x, I(x), I(x), g(x), q)=0$, describes the system model described above, where $x$ is the independent variable (reactor length), $I(x)$ denotes the set of all differential and algebraic variables, $I(x)$ represents the derivative of differential variables with respect to reactor length, $q$ gives the design variables, and $g(x)$ is the control variables. The optimization solution method is a two-step method known as feasible path approach. The first step performs the simulation for converging all the equality constraints (described by $y$ ) as well as for satisfying the inequality constraints. The second step performs the optimization (updates the values of the decision variables) ${ }^{(18)}$. The optimization problem is formulated as a Non-Linear Programming (NLP) problem and is solved utilizing a Successive Quadratic Programming (SQP) method within gPROMS package.

\section{RESULTS AND DISCUSSION}

\subsection{Optimal Results with Model Validation}

The kinetic parameters for naphtha thermal cracking process considered in this work were estimated from the industrial experimental data. In case 1 , the activation energy $(E A j)$, frequency factor $(A j)$ suggested by Pramod and Deepak ${ }^{(17)}$ have been modified for each reaction and calculated simultaneously via optimization process in order to obtain the best kinetic model. The kinetic parameters obtained using non-linear approaches are presented in Table 3 with the chemical reaction scheme of the process.

It is noted from Table 3 depending on the objective function that parameters calculation is more accurate. On the other hands, calculating of activation energy and frequency factor by Pramod and Deepak was carried out by linearizing the Arrhenius equation giving larger error in comparison with simultaneous estimation of kinetic parameters by non-linear (NLN) method. Hence, non-linear approach is employed for describing the behavior of the yield of ethylene and propylene component.

A comparison between the industrial data and model predictions for ethylene and propylene yield plotted in Figures 2-4 at different process variables (coil outlet temperature, feed flow rate and steam to naphtha ratio). It has been observed based on these Figures, the model was found for predicting the behavior of the industrial thermal cracking reactor very well correspondence in the range of process variables with average absolute error (AAE) lower than 1\% (among all the results of the ethylene and propylene yield).

\subsection{Simulations Results of the Industrial Reactor}

The model improved now can be employed for simulating the behavior of the industrial thermal cracking reactor at various process variables for which the industrial data are not available. Table 4 shows the operation variables other than the industrial experimental 
conditions. For simulating the steady performance of the reactor within the software, the mathematical model relations should be provided. When the feed characterizations, reactor temperature, feed flow rate and steam to naphtha ratio are provided, the product yield and profiles will be obtained ${ }^{(2)}$.

This work focuses on the tubular reactors and cracking reactions in these reactors. The effect of operating conditions upon the ethylene and propylene product yields beside the rate coking formation based on industrial thermal cracking reactors, which have not widely studied in the literature, will be investigated here. The influence of process conditions upon the ethylene and propylene product yields and coking rate have been estimated by changing the operation conditions of these reactors. In the whole tubular reactor, the outlet temperature of the reactor should be the highest. Therefore, the coking behavior at the tube outlet is checked.

Figures 5-10 show the impact of the coil outlet temperature, feed flow rate and steam to naphtha ratio on the yield of ethylene and propylene and upon the coke deposition. An increase in coil outlet temperature, the ethylene as well as the rate of coke deposition will increase. Owing to these impacts, the profile of the temperature along the reactor has an optimal. At maximum coking rate, the coking is building up quicker at the inside wall of the tube and the interval between decoking is lowering. In general, decoking process of the reactor requires the plant to be taken off-line for 1-2 days leading to negative influence on the overall production rate ${ }^{(19)}$.

It has also been observed from these Figures that the ethylene yield and coke deposition is decreasing as increasing in feed flow rate. This behavior is attributed to decrease in contact time and thus the reaction severity will decrease. On the other hand, as the residence time is decreased, the amount of the reactions rates is necessary ${ }^{(20)}$.

As well as, these Figures showed that an increase in steam to naphtha ratio (which means the lowering of the partial pressure of naphtha in the feed) will decrease the rate of coke deposition and increase the ethylene yield. Despite this behavior is favorable from the point of view of productivity, but uneconomical due to increase in the cost of the process. The optimal value of the steam to naphtha ratio found in the public domain is about 0.6 to 0.8 $(1,19)$.

\subsection{Optimal Operation Results}

For the optimal operation in this work, process profit is employed as the objective function with satisfying all the equality and inequality constraints. The process gas temperature profile has a significant impact upon the product yields. The most profitable process variables will be difficult including the product yield, the coking rate, steam dilution and temperature profile resulting to appreciable downtime in process. The simulation results 
mentioned previously indicate that the most sensitive decision variable is probably to be the imposed reaction temperature behavior followed by the $\mathrm{S} / \mathrm{N}$ ratio. Thus, it is necessary to obtain of such variables related to the objective function. The values of the key parameters utilized in this work with their notations are introduced in Table $5^{(21)}$. The modeling, simulation and optimization process is achieved via utilizing gPROMS package and Successive Quadratic Programming (SQP) solver based on a Non-Linear Programming (NLP) problem.

Also, on the aims of this strategy is to control the coil outlet temperature (COT), which is measured via the gas temperature $(\mathrm{Tg})$. The furnace wall temperature against relative reactor length at different coil outlet temperature is plotted in Figure 11. As can be seen from this Figure, the furnace wall temperature in the middle of the reactor is very high leading to increase in the coking formed and needs a tube with a maximum allowable wall temperature. The developed mathematical model has been utilized for obtaining the optimum gas temperature strategy employing the objective function explained previously. Giving the optimum gas temperature behavior and utilizing heat balance, the desired furnace wall temperature behavior is achieved. This required will be employed as set points for wall temperature control loops. The optimal temperature policy result is shown in Figure 12.

The optimization results of the case study 2 and the comparison results obtained from this study and those achieved by previous studies are summarized in Table 6. It can be observed from this Table, the operating profit has been improved clearly. The optimal coil outlet temperature of the process with satisfying all the inequality constraints of the tubular reactor is $867.17^{\circ} \mathrm{C}$ and maximum objective function is $237585 \$ /$ Year at the optimal operating condition and higher than those achieved by last studies.

The product yields of the cracking reaction are higher leading to increase the profit. Owing to increase the temperature along the tube length (at the optimum temperature profile), the coking rate will be high and the process becomes uneconomic as a result of decoking process caused by tubular reactor shutdown. Therefore, the optimal steam to naphtha ratio in the feed has been obtained within the range reported the literature $(0.6-0.8)$ to be 0.682 optimal value. Hence the production decoking time between two consecutives reduced up to 20 days (less than time obtained in comparison with previous works.

It is clearly observed from this Table based on the results obtained (where the yield of ethylene and propylene, production time and the objective function in comparison with previous studies, has improved) that the modified kinetic parameters is important. Also, the new approach (successive quadratic programming) used in this study for maximizing the profit is better than the methods employed with all previous works that utilized various solvers to maximize the objective function to achieve the optimal design of naphtha thermal 
cracking reactor. This new results is attributed to the SQP method utilized in this study, which has high accuracy in estimating the decision parameters of the operation within gPROMS software (sophisticated tools as well as formalisms for model development that allow to describe the complex models adequately and has many specifications, which make it an active tool and convenient for the modeling, simulation and optimization of any unit operation). As well as, this method is a highly trusted method for solution of such mathematical models.

\section{CONCLUSIONS}

In the present study, an optimal design of an industrial thermal cracking reactor is investigated here within gPROMS Model Builder and an optimization framework was developed in order to tackle the optimal design and process problem of such reactor. The optimization problem formulations have been introduced. Evaluation of the kinetic factors in the industrial reactor for naphtha thermal cracking process is required for developing a model with high accuracy, thus the model can be effectively employed for simulation, optimization and design. Evaluation of the key factors of the kinetic model of such reactions has been estimated utilizing a real experimental data and an optimization process. To calculate the best values of these factors, non-linear approach has been implemented, where the activation energy, frequency factor, reaction order have been estimated simultaneously. Based upon the objective function ( $S S E$ ), the factors determined were found to be more accurate and the simulation results showed very well agreement with the data obtained with an AAE lower than $1 \%$.

The mathematical model developed with taking into considerations the coking rate through various cases is then utilized for simulating the process behavior and studying the influence of operation variables (mainly, coil outlet temperature, steam to naphtha ratio and feed flow rate) upon the product yield and on the coke deposition. It has been observed that high temperature, stem to naphtha ratio and low feed flow rate improve the ethylene yield. Whereas, decreasing in temperature and increasing in steam to naphtha ration as well as feed flow rate, low coke deposition was obtained.

The optimum temperature control of the thermal cracking reactor is investigated. Utilizing the objective function, the optimum temperature performance has been achieved, and the corresponding furnace wall temperature trajectory has also been estimated. Following the best control process, the optimal temperature policy is utilized to the reactor. Finally, the optimal decision variables via successive quadratic programming solution method based on 
non-liner approach were obtained and higher profit of the process compared with the last studies has been improved.

\section{REFERENCES}

1. M. Masoumi, S.M. Sadrameli, J. Towfighi and A. Niaei "Simulation, optimization and control of a thermal cracking furnace" Energy, Elsevier-science direct, vol. 31, no.4, pp: 516-527, 2006.

2. M. Masoumi, M. Shahrokhi, M. Sadrameli and J. Towfighi "Modeling and Control of a Naphtha Thermal Cracking Pilot Plant" Ind. Eng. Chem. Res., ACS, vol. 45, no.10, pp: 3574-3582, 2006.

3. M. Shahrokhi "Simulation and Optimization a Naphtha Thermal Cracking Pilot Plant" Ir. J. Chem \& Chem. Eng., SID, vol. 22, no.1, pp: 27-35, 2003.

4. J. Cugini "Computer Control of Ethylene Plant Cracking Furnaces" Symposium on Characterization of Thermodynamics and Transport Properties of Polymer System, New Orleans, LA, USA, Apr 1986.

5. F.D. Kopinke, G. Zimmermann, G.F. Froment, and G.C. Reyniers "Relative Rates of Coke Formation from Hydrocarbon in Steam Cracking of Naphtha. 2. Paraffins, Naphthenes, Mono-, Di-, and Cycloolefins, and Acetylenes" Ind. Eng. Chem. Res., ACS, vol. 32, no. 1, pp: 55-61, 1993.

6. F.D. Kopinke, G. Zimmermann, G.F. Froment, and G.C. Reyniers "Relative Rates of Coke Formation from Hydrocarbons in Steam Cracking of Naphtha. 2. Aromatic Hydrocarbons" Ind. Eng. Chem. Res., ACS, vol. 32, no. 11, pp: 2620-2625, 1993.

7. M. Shahrokhi and A. Nejati "Optimal Temperature Control of a Propane Thermal Cracking Reactor" Ind. Eng. Chem. Res., ACS, vol. 41, no. 25, pp: 6572-6578, 2002.

8. Arak petrochemical Company, http://www.chemnet.com/IranSuppliers/9975/, 2014.

9. X. Lan, J. Gao, C. Xu and H. Zhang "Numerical Simulation of Transfer and Reaction Processes in Ethylene Furnaces" Chemical Engineering Research and Design, Trans IChemE, Part A, vol. 85, no. 12, pp:1565-1579, 2007.

10. G.Y. Gao, M. Wang, C.C. Pantelides, X.G. Li and H. Yeung "Mathematical Modeling and Optimal Operation of Industrial Tubular Reactor for Naphtha Cracking" Computer Aided Chemical Engineering, Elsevier-science direct, vol. 27, part A, pp: 501-506, 2009.

11. A. Niaei, J. Towfighi, S.M. Sadrameli and R. Karimzadeh "The combined simulation of heat transfer and pyrolysis reactions in industrial cracking furnaces" Applied Thermal Energy, Elsevier-science direct, vol. 24, no.14-15, pp: 2251-2265, 2004. 
12. J. Towfighi, and H. Nazari "Simulation of Light Hydrocarbons Pyrolysis Using Radical Mechanism", in: Proceedings of APCCHE/CHEMECA'93, Melbourne, Australia, 1993.

13. K.M. Sundaram, M.M. Shreehan and E.F. Olszewski "Kirk-Othmer Encyclopedia of Chemical Technology" $5^{\text {th }}$ ed., John Wiley \& Sons, 2002.

14. R.C. Reid, J.M. Prausnitz and B.E. Poling, "The Properties of Gases \& Liquids". $4^{\text {th }}$ ed. New York, McGraw-Hill, 1987.

15. M.R. Riazi "Characterization and Properties of Petroleum Fractions" $1^{\text {st }}$ ed. ASTM International, Philadelphia, USA, 2005.

16. J. Towfighi, J. Modarres and M. Omidkhah "Estimation of kinetic parameters of coking reaction rate in pyrolysis of naphtha" IJE TRANSACTIONS B: Applications, vol. 17, no.4, pp: 319-332, 2004.

17. K. Pramod and K. Deepak "Modeling of Naphtha Pyrolysis" Ind. Eng. Chem. Res., ACS, vol. 24, no. 3, pp: 774-782, 1985.

18. A.T. Jarullah, Sh.A. Hameed and Z.A. Hammed "Optimal Design of Ammonia Synthesis Reactor" Tikrit Journal of Engineering Sciences, vol.20, no.3, pp: 22-31, 2013.

19. G.Y. Gao, M. Wang, C. Ramshaw, X.G. Li and H. Yeung "Optimal operation of tubular reactors for naphtha cracking by numerical simulation" Asia-Pasific journal of Chemical Engineering, vol. 4, no. 6, pp: 885-892, 2009.

20. R.M.V. Rao, M.P. Plehiers and G.F. Froment GF. "The coupled simulation of heat transfer and reaction in a pyrolysis furnace" Chemical Engineering Science, ElsevierScience Direct, vol. 42, no.6, pp: 1223-1229, 1998.

21. ICIS Chemical Business, "Chemical Week Price Report" https:/www.icis.com, (2006).

22. Y.F. Hu, Y.M. Xu and X.O.He "Modeling and Simulation of Naphtha Pyrolysis" Ind. Eng. Chem. Res., ACS, vol. 20, no. 6, pp: 51-57, 2004.

Table (1): Naphtha feedstock composition (wt)

\begin{tabular}{|l|l|l|l|l|}
\hline No of Carbons & normal-Paraffins & iso-Paraffins & Naphthens & Aromatics \\
\hline Four & 0.0022 & .0264 & - & - \\
\hline Five & 0.2522 & 0.1794 & 0.0419 & - \\
\hline Six & 0.1488 & 0.2341 & 0.0282 & 0.02 \\
\hline Seven & 0.0167 & 0.0327 & - & 0.0097 \\
\hline Eight & - & 0.0057 & - & 0.002 \\
\hline Total & 0.4199 & 0.4783 & 0.0701 & 0.0317 \\
\hline
\end{tabular}


OPTIMAL DESIGN OF INDUSTRIAL REACTOR FOR NAPHTHA THERMAL CRACKING PROCESS

Table (2): Reactor configuration and basic information of cracking process

\begin{tabular}{|c|c|}
\hline Characteristic & Values \\
\hline Total Reactor Length & $21.544 \mathrm{~m}$ \\
\hline Reactor Diameter & $0.09 \mathrm{~m}$ \\
\hline Tube Spacing & $0.127 \mathrm{~m}$ \\
\hline Number of Reactor Tubes & 40 \\
\hline Highest Temperature Allowed for Tube & $1100^{\circ} \mathrm{C}$ \\
\hline Radius of the bend & $0.128 \mathrm{~m}$ \\
\hline $\mathrm{H}_{2} \quad$ Fuel Composition \\
\hline $\mathrm{CH}_{4}$ & $14 \mathrm{wt} \%$ \\
\hline Excess Air & $86 \mathrm{wt} \%$ \\
\hline
\end{tabular}

Table (3): Chemical reaction scheme and optimal kinetic parameters for case 1

\begin{tabular}{|c|c|c|c|}
\hline Reaction Equation & Rate Description & $\begin{array}{l}A_{i}\left(\mathrm{sec}^{-1} \text { or }\right. \\
\left.\mathrm{cm}^{3} / \mathrm{mol} . \mathrm{sec}\right)\end{array}$ & $E_{i}(\mathbf{J} / \mathbf{m o l})$ \\
\hline $\begin{array}{l}\mathrm{C}_{6.5} \mathrm{H}_{14} \rightarrow 0.5 \mathrm{H}_{2}+0.76 \mathrm{CH}_{4} \\
+1.16 \mathrm{C}_{2} \mathrm{H}_{4}+0.13 \mathrm{C}_{2} \mathrm{H}_{6}+0.38 \mathrm{C}_{3} \mathrm{H}_{6}+ \\
0.09 \mathrm{C}_{3} \mathrm{H}_{8}+0.008 \mathrm{C}_{4} \mathrm{H}_{10}+0.245 \mathrm{C}_{4} \mathrm{H}_{8} \\
+0.113 \mathrm{C}_{4} \mathrm{H}_{6}+0.08 \mathrm{C}_{4}\end{array}$ & $r_{I}=k_{l} \times C_{C 6.5 H I}$ & $\mathrm{~A}_{1}=5.843 \times 10^{13}$ & $E_{1}=219994.72$ \\
\hline $\mathrm{C}_{2} \mathrm{H}_{6} \leftrightarrow \mathrm{C}_{2} \mathrm{H}_{4}+\mathrm{H}_{2}$ & $\begin{array}{l}r_{2}=k_{21}\left(C_{C 2 H 6}-C_{C 2 H 4} \cdot C_{H 2} / k_{22}\right) \\
K_{R 2}=k_{21} / k_{22}\end{array}$ & $\begin{array}{l}\mathrm{A}_{21}=7.012 \times 10^{14} \\
\mathrm{~A}_{22}=8.867 \times 10^{10}\end{array}$ & $\begin{array}{l}E_{21}=279764.54 \\
E_{R 2}=139668.32\end{array}$ \\
\hline $\mathrm{C}_{3} \mathrm{H}_{6} \leftrightarrow \mathrm{C}_{2} \mathrm{H}_{2}+\mathrm{CH}_{4}$ & $\begin{array}{l}r_{3}=k_{31}\left(C_{C 3 H 6}-C_{C 2 H 2} \cdot C_{C H 4} / k_{32}\right) \\
K_{R 3}=k_{31} / k_{32}\end{array}$ & $\begin{array}{l}\mathrm{A}_{31}=5.987 \times 10^{14} \\
\mathrm{~A}_{23}=5.333 \times 10^{9}\end{array}$ & $\begin{array}{l}E_{31}=277602.76 \\
E_{R 3}=150001.84\end{array}$ \\
\hline $\mathrm{C}_{2} \mathrm{H}_{2}+\mathrm{C}_{2} \mathrm{H}_{4} \rightarrow \mathrm{C}_{4} \mathrm{H}_{6}$ & $r_{4}=k_{4} \cdot C_{C 2 H 2} \cdot C_{C 2 H 4}$ & $\mathrm{~A}_{4}=1.929 \times 10^{17}$ & $\mathrm{E}_{4}=176134.66$ \\
\hline $2 \mathrm{C}_{2} \mathrm{H}_{6} \rightarrow \mathrm{C}_{3} \mathrm{H}_{8}+\mathrm{CH}_{4}$ & $r_{5}=k_{5} \cdot C_{C 2 H 6}$ & $\mathrm{~A}_{5}=4.231 \times 10^{14}$ & $E_{5}=274996.22$ \\
\hline $\mathrm{C}_{2} \mathrm{H}_{4}+\mathrm{C}_{2} \mathrm{H}_{6} \rightarrow \mathrm{C}_{3} \mathrm{H}_{6}+\mathrm{CH}_{4}$ & $r_{6}=k_{6} C_{C 2 H 4} \cdot C_{C 2 H 6}$ & $\mathrm{~A}_{6}=6.503 \times 10^{17}$ & $\mathrm{E}_{6}=257964.76$ \\
\hline $\mathrm{C}_{3} \mathrm{H}_{8} \leftrightarrow \mathrm{C}_{3} \mathrm{H}_{6}+\mathrm{H}_{2}$ & $\begin{array}{l}r_{7}=k_{71}\left(C_{C 3 H 8}-C_{C 3 H 6} \cdot C_{C H 2} / k_{72}\right) \\
K_{R 7}=k_{71} / k_{72}\end{array}$ & $\begin{array}{l}\mathrm{A}_{71}=3.414 \times 10^{13} \\
\mathrm{~A}_{\mathrm{R} 7}=8.111 \times 10^{8}\end{array}$ & $\begin{array}{l}E_{71}=218099.41 \\
E_{R 7}=100103.19\end{array}$ \\
\hline $\mathrm{C}_{3} \mathrm{H}_{8} \rightarrow \mathrm{C}_{2} \mathrm{H}_{4}+\mathrm{CH}_{4}$ & $r 8=k 8 . C_{C 3 H 8}$ & $\mathrm{~A}_{8}=2.087 \times 10^{18}$ & $\mathrm{E}_{8}=214988.33$ \\
\hline $\mathrm{C}_{3} \mathrm{H}_{8}+\mathrm{C}_{2} \mathrm{H}_{4} \rightarrow \mathrm{C}_{2} \mathrm{H}_{6}+\mathrm{C}_{3} \mathrm{H}_{6}$ & $r_{9}=k_{9} \cdot C_{C 3 H 8} \cdot C_{C 2 H 4}$ & $\mathrm{~A}_{9}=2.636 \times 10^{19}$ & $\mathrm{E}_{9}=251066.12$ \\
\hline $2 \mathrm{C}_{3} \mathrm{H}_{6} \rightarrow 3 \mathrm{C}_{2} \mathrm{H}_{4}$ & $r_{10}=k_{10} \cdot C_{C 3 H 6}$ & $\mathrm{~A}_{10}=6.831 \times 10^{15}$ & $\mathrm{E}_{10}=273361.02$ \\
\hline $2 \mathrm{C}_{3} \mathrm{H}_{6} \rightarrow 0.3 \mathrm{C}_{\mathrm{n}} \mathrm{H}_{2 \mathrm{n} 6}+0.14 \mathrm{C}_{6}+3 \mathrm{CH}_{4}$ & $r_{11}=k_{11} \cdot C_{C 3 H 6}$ & $\mathrm{~A}_{11}=1.879 \times 10^{18}$ & $\mathrm{E}_{11}=244003.34$ \\
\hline $\mathrm{C}_{3} \mathrm{H}_{6}+\mathrm{C}_{2} \mathrm{H}_{6} \rightarrow \mathrm{C}_{4} \mathrm{H}_{8}+\mathrm{CH}_{4}$ & $r_{12}=k_{12}\left(C_{C 3 H 6} \cdot C_{C 2 H 6}\right)$ & $\mathrm{A}_{12}=1.256 \times 10^{19}$ & $\mathrm{E}_{12}=256771.54$ \\
\hline $\mathrm{C}_{4} \mathrm{H}_{10} \rightarrow \mathrm{C}_{3} \mathrm{H}_{6}+\mathrm{CH}_{4}$ & $r_{13}=k_{13} \cdot C_{C 4 H 10}$ & $\mathrm{~A}_{13}=5.961 \times 10^{14}$ & $\mathrm{E}_{13}=255077.32$ \\
\hline $\mathrm{C}_{4} \mathrm{H}_{10} \rightarrow 2 \mathrm{C}_{2} \mathrm{H}_{4}+\mathrm{H}_{2}$ & $r_{14}=k_{14} \cdot C_{C 4 H 10}$ & $\mathrm{~A}_{14}=6.678 \times 10^{16}$ & $\mathrm{E}_{14}=296989.88$ \\
\hline $\mathrm{C}_{4} \mathrm{H}_{10} \rightarrow \mathrm{C}_{2} \mathrm{H}_{4}+\mathrm{C}_{2} \mathrm{H}_{6}$ & $r_{15}=k_{15} \cdot C_{C 4 H 10}$ & $\mathrm{~A}_{15}=3.137 \times 10^{13}$ & $E_{15}=260498.55$ \\
\hline $\mathrm{C}_{4} \mathrm{H}_{10} \leftrightarrow \mathrm{C}_{4} \mathrm{H}_{8}+\mathrm{H}_{2}$ & $\begin{array}{l}r_{16}=k_{161}\left(C_{C 4 H 10}-C_{C 4 H 8} . C_{H 2} / k_{162}\right) \\
K_{R 16}=k_{161} / k_{162}\end{array}$ & $\begin{array}{l}A_{161}=2.022 \times 10^{13} \\
A_{R 16}=2.666 \times 10^{8}\end{array}$ & $\begin{array}{l}E_{161}=266003.91 \\
E_{R 16}=139111.83\end{array}$ \\
\hline $\mathrm{C}_{4} \mathrm{H}_{8} \rightarrow 0.41 \mathrm{C}_{\mathrm{n}} \mathrm{H}_{2 \mathrm{n}-6}+0.19 \mathrm{C}^{+}{ }_{6}$ & $r_{17}=k_{17} \cdot C_{C 4 H 8}$ & $\mathrm{~A}_{17}=2.843 \times 10^{14}$ & $\mathrm{E}_{17}=217765.22$ \\
\hline $\mathrm{C}_{4} \mathrm{H}_{8} \rightarrow \mathrm{H}_{2}+\mathrm{C}_{4} \mathrm{H}_{6}$ & $r_{18}=k_{18} \cdot C_{C 4 H 8}$ & $\mathrm{~A}_{18}=2.347 \times 10^{11}$ & $E_{18}=213456.44$ \\
\hline $\mathrm{C}_{2} \mathrm{H}_{4}+\mathrm{C}_{4} \mathrm{H}_{6} \rightarrow \mathrm{C}_{6} \mathrm{H}_{6}+2 \mathrm{H}_{2}$ & $r_{19}=k_{19} \cdot C_{C 2 H 4} \cdot C_{C 4 H 6}$ & $\mathrm{~A}_{19}=6.952 \times 10^{15}$ & $\mathrm{E}_{19}=148124.81$ \\
\hline $\mathrm{C}_{4} \mathrm{H}_{6}+\mathrm{C}_{3} \mathrm{H}_{6} \rightarrow \mathrm{C}_{7} \mathrm{H}_{8}+2 \mathrm{H}_{2}$ & $r_{20}=k_{20} \cdot C_{C 4 H 6} \cdot C_{C 3 H 6}$ & $\mathrm{~A}_{20}=8.653 \times 10^{14}$ & $\mathrm{E}_{20}=150293.99$ \\
\hline $\mathrm{C}_{4} \mathrm{H}_{6}+\mathrm{C}_{4} \mathrm{H}_{8} \rightarrow \mathrm{C}_{8} \mathrm{H}_{10}+2 \mathrm{H}_{2}$ & $r_{21}=k_{21} \cdot C_{C 4 H 6} \cdot C_{C 4 H 8}$ & $\mathrm{~A}_{21}=3.878 \times 10^{19}$ & $\mathrm{E}_{21}=24528611$ \\
\hline $\mathrm{C}_{4} \mathrm{H}_{6}+\mathrm{C}_{4} \mathrm{H}_{6} \rightarrow \mathrm{C}_{8} \mathrm{H}_{8}+2 \mathrm{H}_{2}$ & $r_{22}=k_{22} \cdot C_{C 4 H 6} \cdot C_{C 4 H 6}$ & $\mathrm{~A}_{22}=2.085 \times 10^{13}$ & $\mathrm{E}_{22}=127687.33$ \\
\hline
\end{tabular}

Table (4): Operating variables

\begin{tabular}{|c|c|}
\hline Operating Variables & Values \\
\hline Input Temperature & $873 \mathrm{~K}$ \\
\hline Input Pressure & $3 \mathrm{~atm}(\mathrm{abs})$. \\
\hline Feed Flow Rate & $1388.34-4166.68 \mathrm{~g} / \mathrm{s}$ \\
\hline COT & $830-900^{\circ} \mathrm{C}$ \\
\hline S/N & $0.2-0.9$ \\
\hline
\end{tabular}


Table (5): Key parameters of optimization process (case 2).

\begin{tabular}{|l|l|l|}
\hline \multicolumn{1}{|c|}{ Name } & \multicolumn{1}{c|}{ Parameters } & \multicolumn{1}{c|}{ Values } \\
\hline Propylene Price Factor & $\operatorname{Pr}_{C_{3} H_{6}}$ & $1196 \$ /$ ton \\
\hline Ethylene Price Factor & $\operatorname{Pr}_{C_{2} \mathrm{H}_{4}}$ & $1350 \$ /$ ton \\
\hline Naphtha Price Factor & $\operatorname{Pr}_{\text {naphtha }}$ & $541 \$ /$ ton \\
\hline Decoking Time per Period/Cycle & $t_{d}$ & $48 \mathrm{hr}$ \\
\hline Yearly Production Time & $t_{p}$ & $8160 \mathrm{hr}$ \\
\hline Heat Price Factor & $\operatorname{Pr}_{H}$ & $1.26 \times 10^{-5} \$ / \mathrm{kJ}$ \\
\hline Steam Price Factor & $\operatorname{Pr}_{\text {steam }}$ & $0.0129 \$ / \mathrm{kg}$ \\
\hline
\end{tabular}

Table (6): Results of optimization problem for case study 2 and comparison results with previous studies.

\begin{tabular}{|l|l|l|l|l|}
\hline \multicolumn{1}{|c|}{ Parameters } & $\begin{array}{l}\text { Hu et al. } \\
\mathbf{( 2 0 0 4}^{(22)}\end{array}$ & $\begin{array}{l}\text { Gao et al. } \\
\mathbf{( 2 0 0 9 a )}^{(10)}\end{array}$ & $\begin{array}{l}\text { Gao et al. } \\
\mathbf{( 2 0 0 9 b}^{(19)}\end{array}$ & $\begin{array}{c}\text { Optimized Values in } \\
\text { this Study (Aysar }^{\text {et al., 2014) }}\end{array}$ \\
\hline $\mathrm{COT}^{\circ}(\mathrm{C})$ & 827 & 845 & 811 & 864.17 \\
\hline Steam to Naphtha Ratio $(\mathrm{kg} / \mathrm{kg})$ & 0.5 & 0.67 & 0.6 & 0.682 \\
\hline $\mathrm{C}_{3} \mathrm{H}_{6}$ Yield (wt\%) & 14.8 & 13.8 & 12.83 & 14.96 \\
\hline $\mathrm{C}_{2} \mathrm{H}_{4}$ Yield (wt\%) & 31.5 & 34.1 & 29.65 & 36.24 \\
\hline Production Time (days) & 39 & 27 & 21 & 20 \\
\hline Heat Flux (kJ/hr) & 624858 & 759304 & $3.03 \times 10^{7}$ & $2.95 \times 10^{7}$ \\
\hline Objective Function (\$/year) & 70054 & 85291 & 101600 & $\mathbf{2 3 7 5 8 5}$ \\
\hline
\end{tabular}

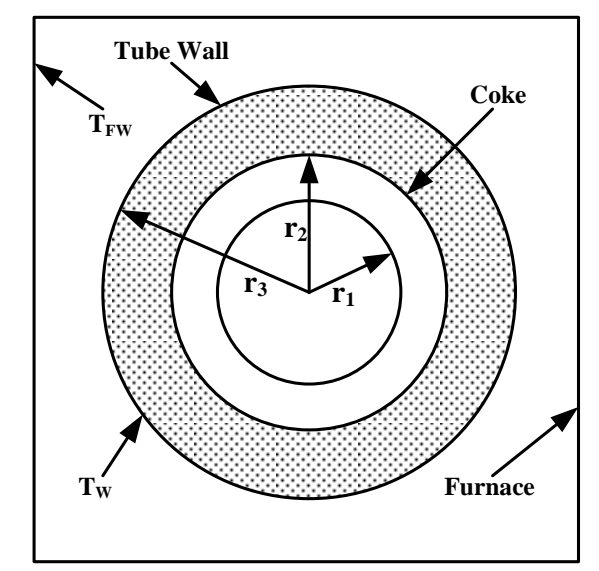

Figure (1): Cross section of reactor tube 


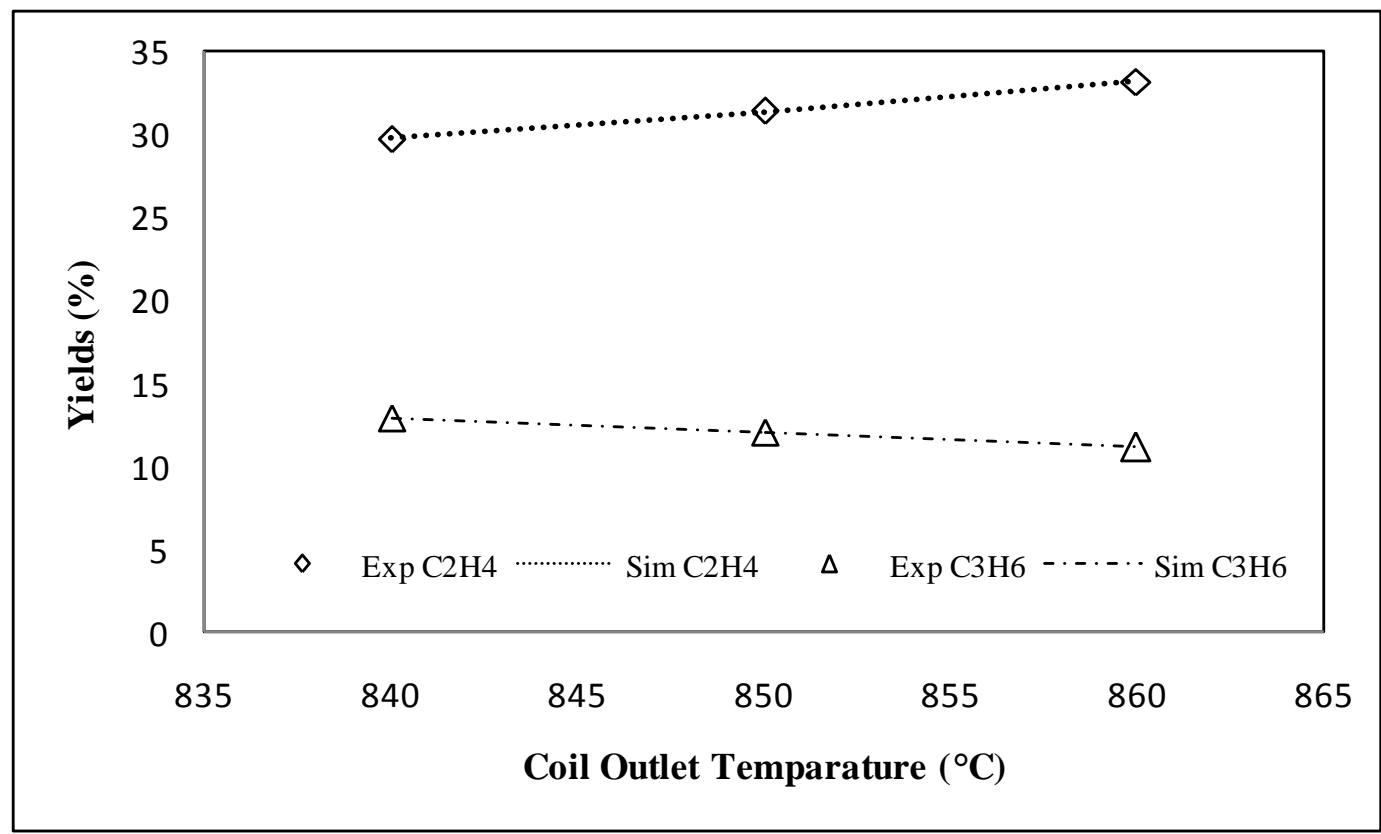

Figure (2): Simulated (lines) and industrial experimental data (points) of ethylene and propylene yields vs. coil outlet temperature

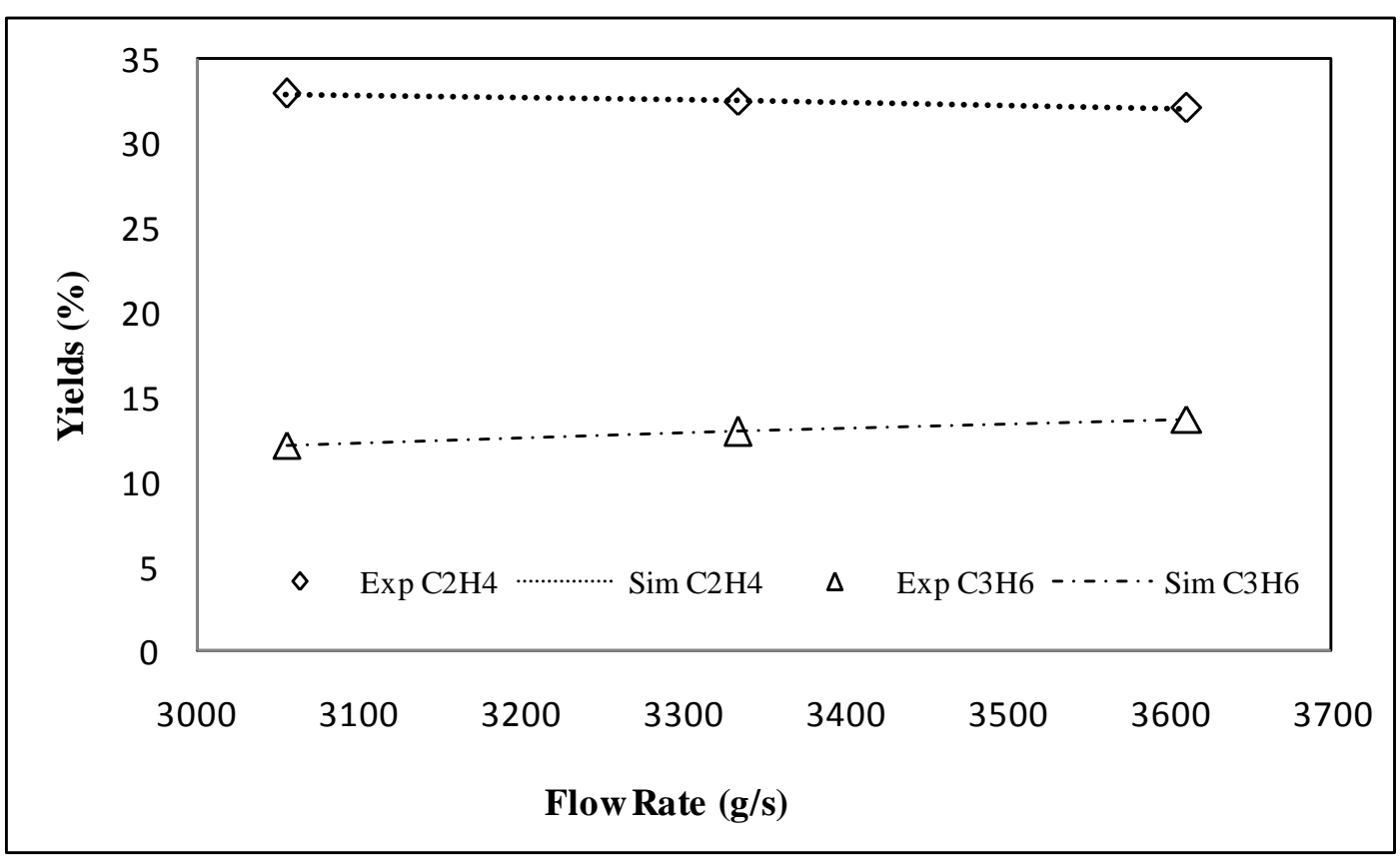

Figure (3): Simulated (lines) and industrial experimental data (points) variation of ethylene and propylene yields vs. feed flow rate 


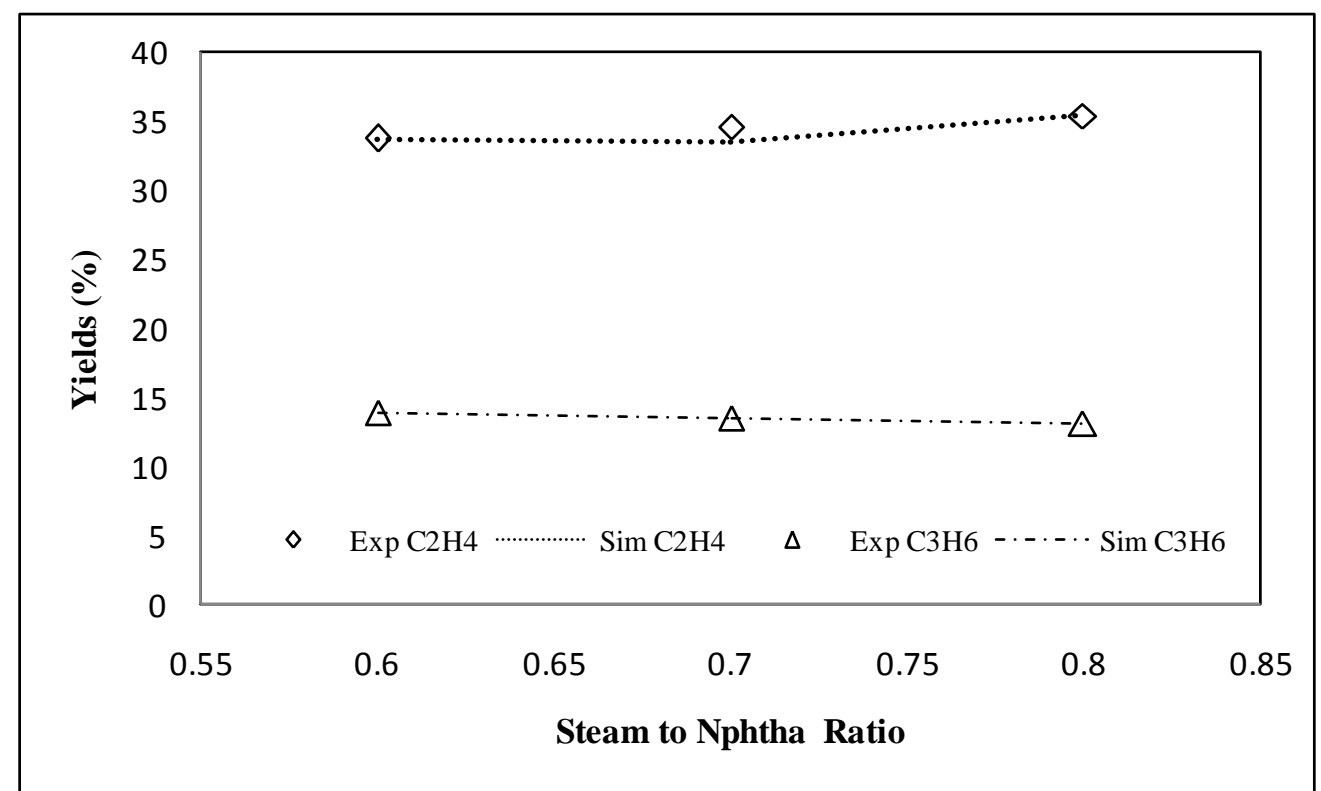

Figure (4): Simulated (lines) and industrial experimental data (points) variation of ethylene and propylene yields vs. steam to naphtha ratio $(\mathrm{S} / \mathrm{N})$

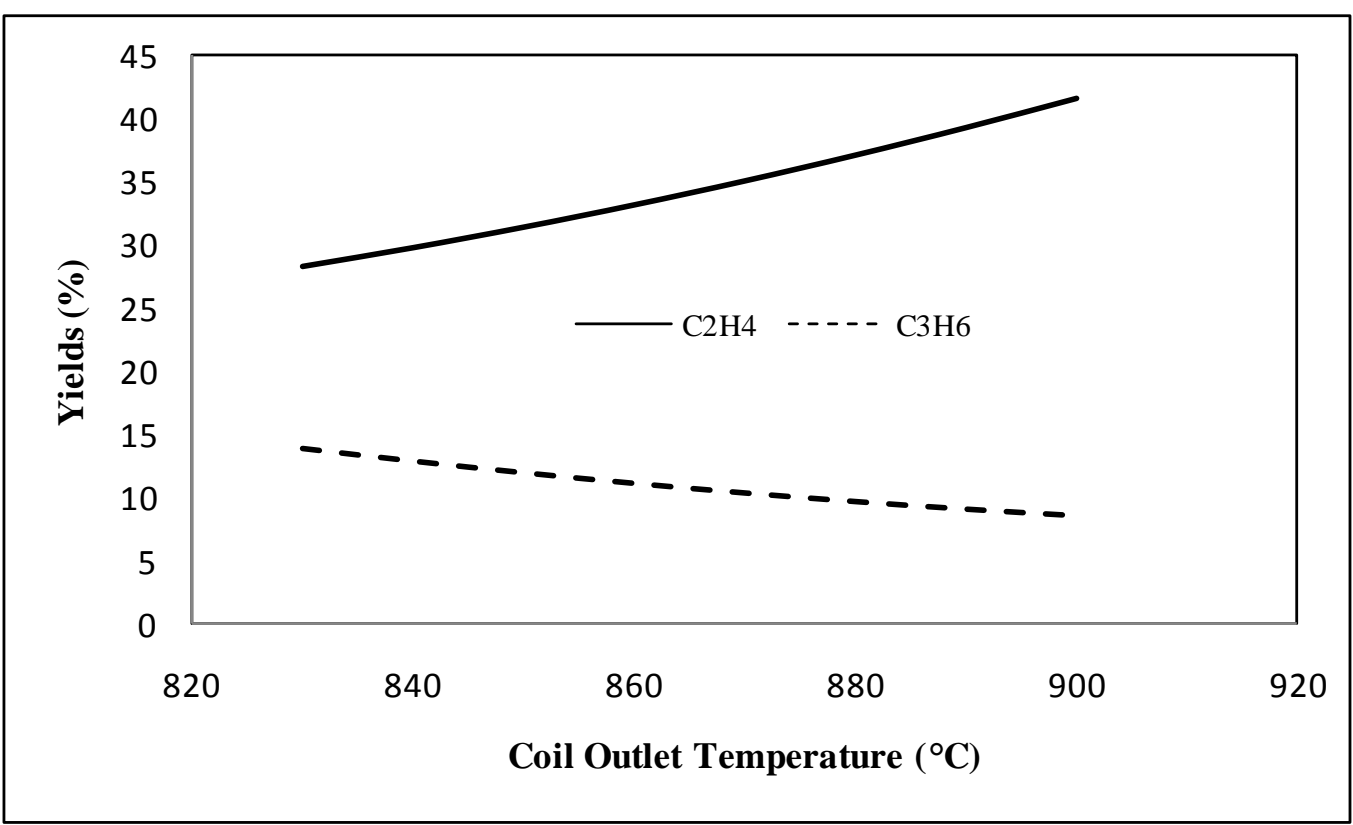

Figure (5): Yields of ethylene and propylene vs. different coil outlet temperature 


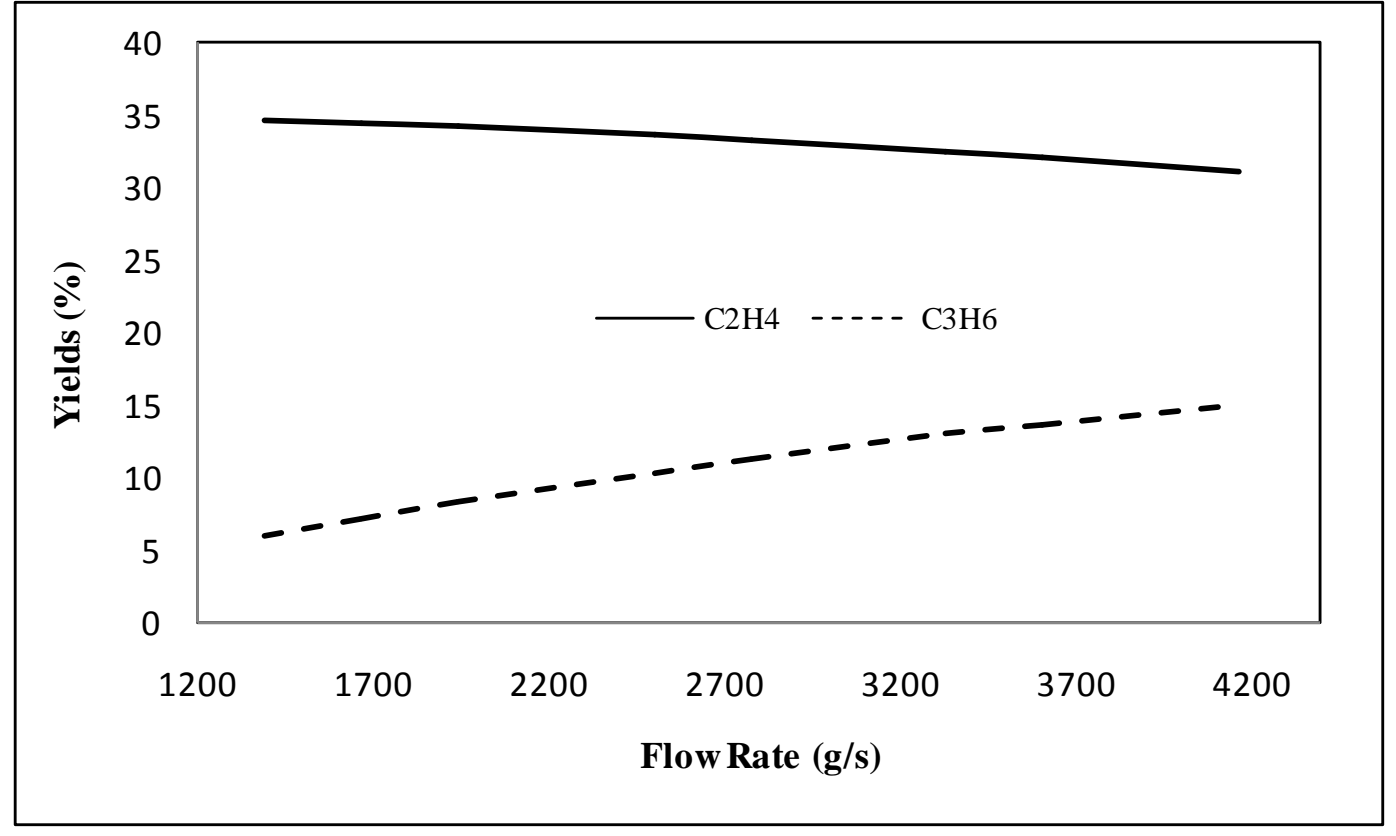

Figure (6): Yields of ethylene and propylene vs. feed flow rates

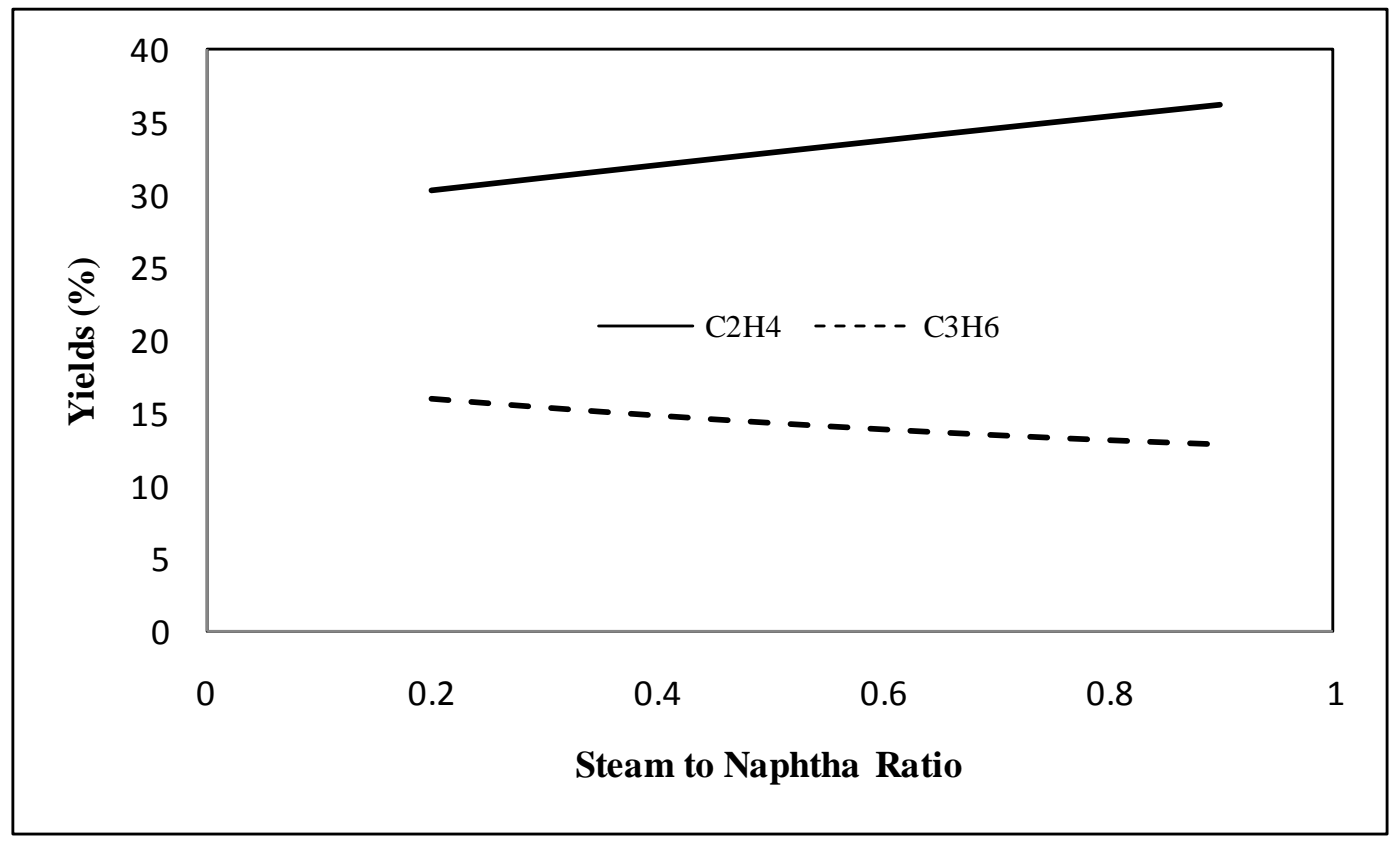

Figure (7): Yields of ethylene and propylene vs. steam to naphtha ratios 


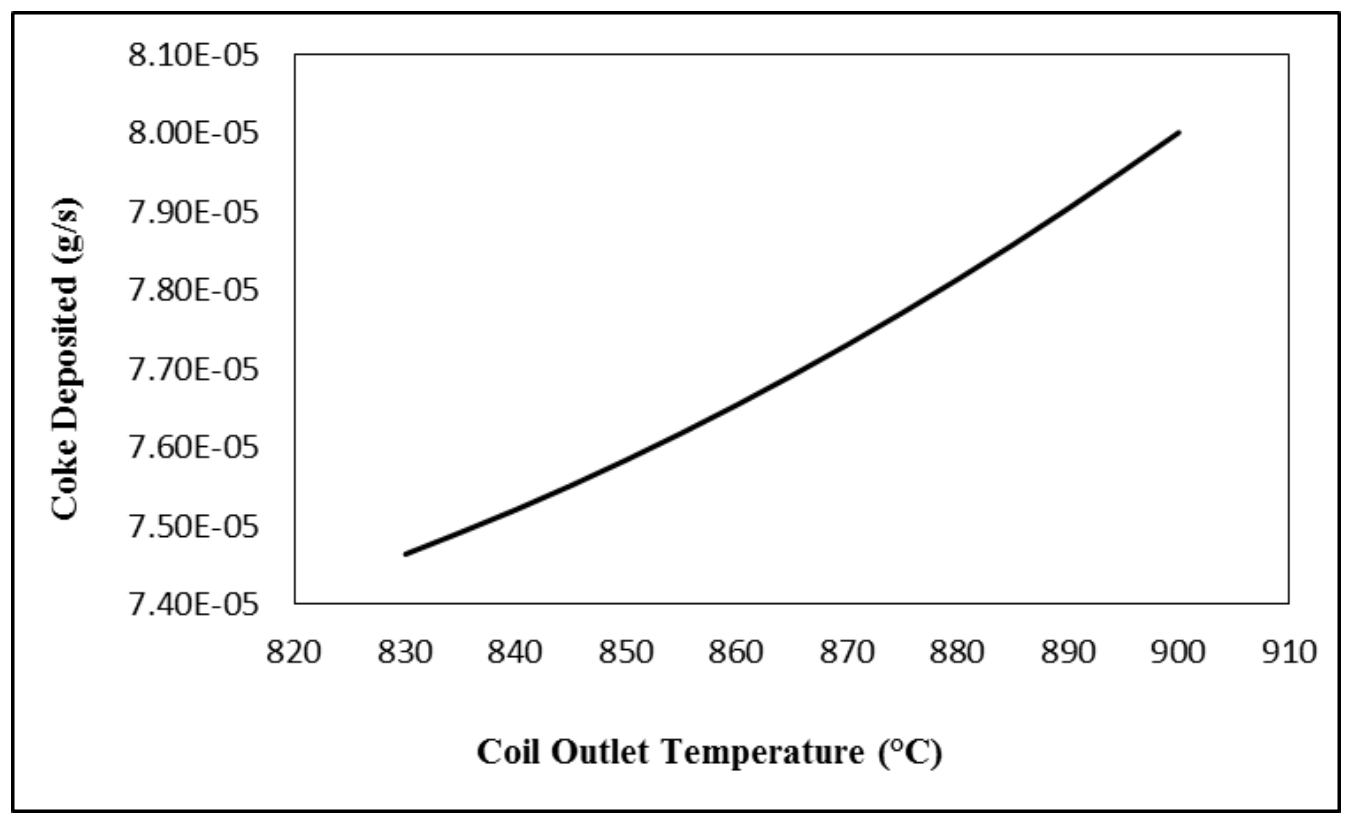

Figure (8): Coke deposited vs. coil outlet temperature

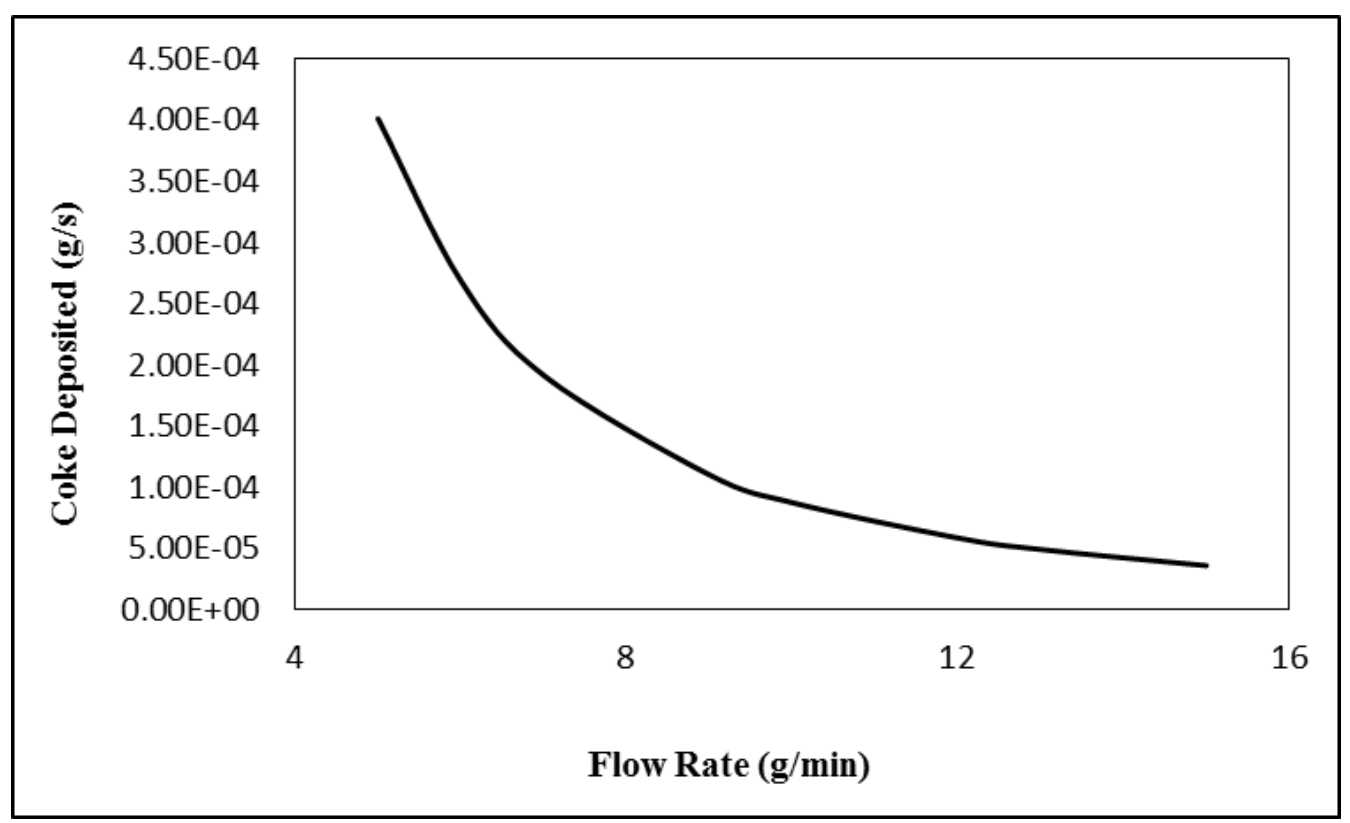

Figure (9): Coke deposited vs. feed flow rates 


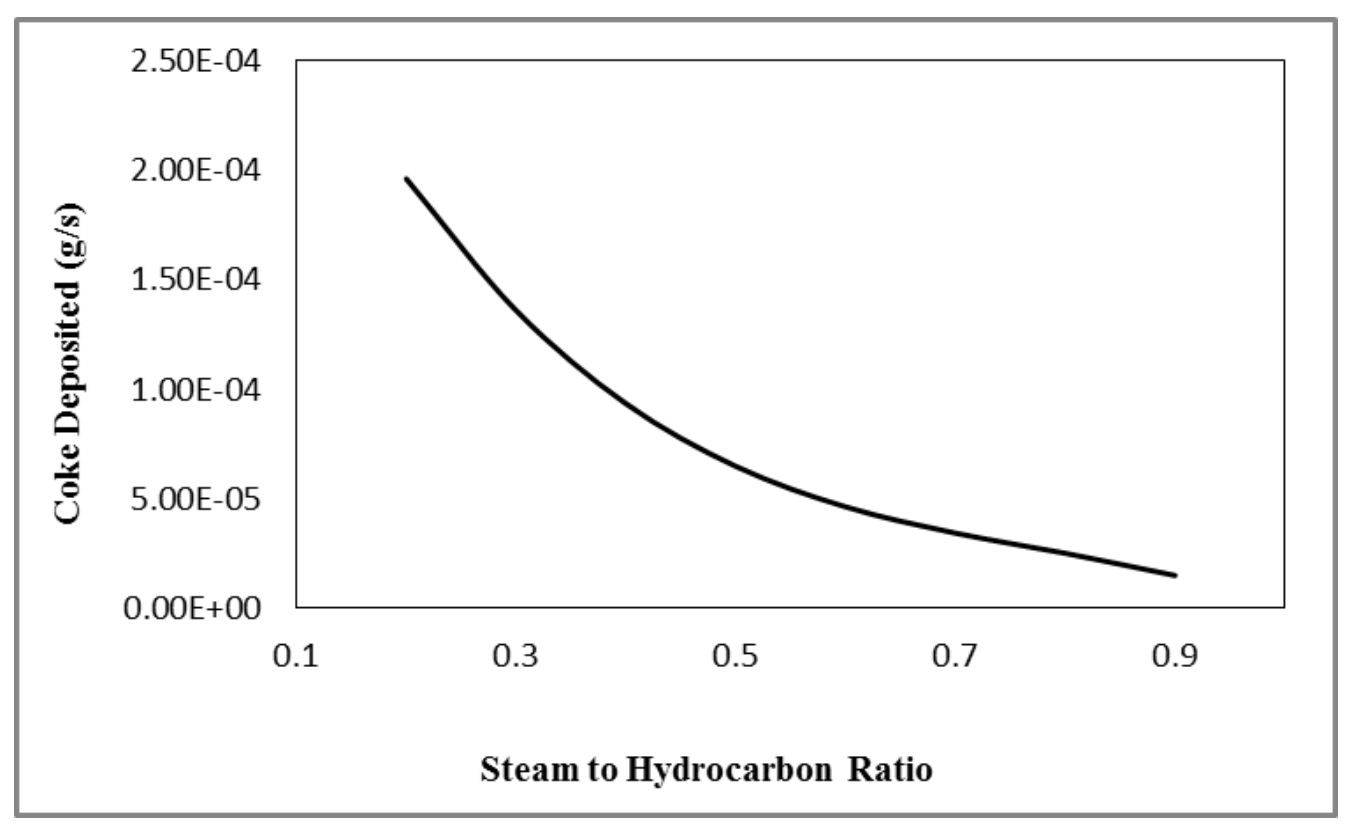

Figure (10): Coke deposited vs. steam to naphtha ratios

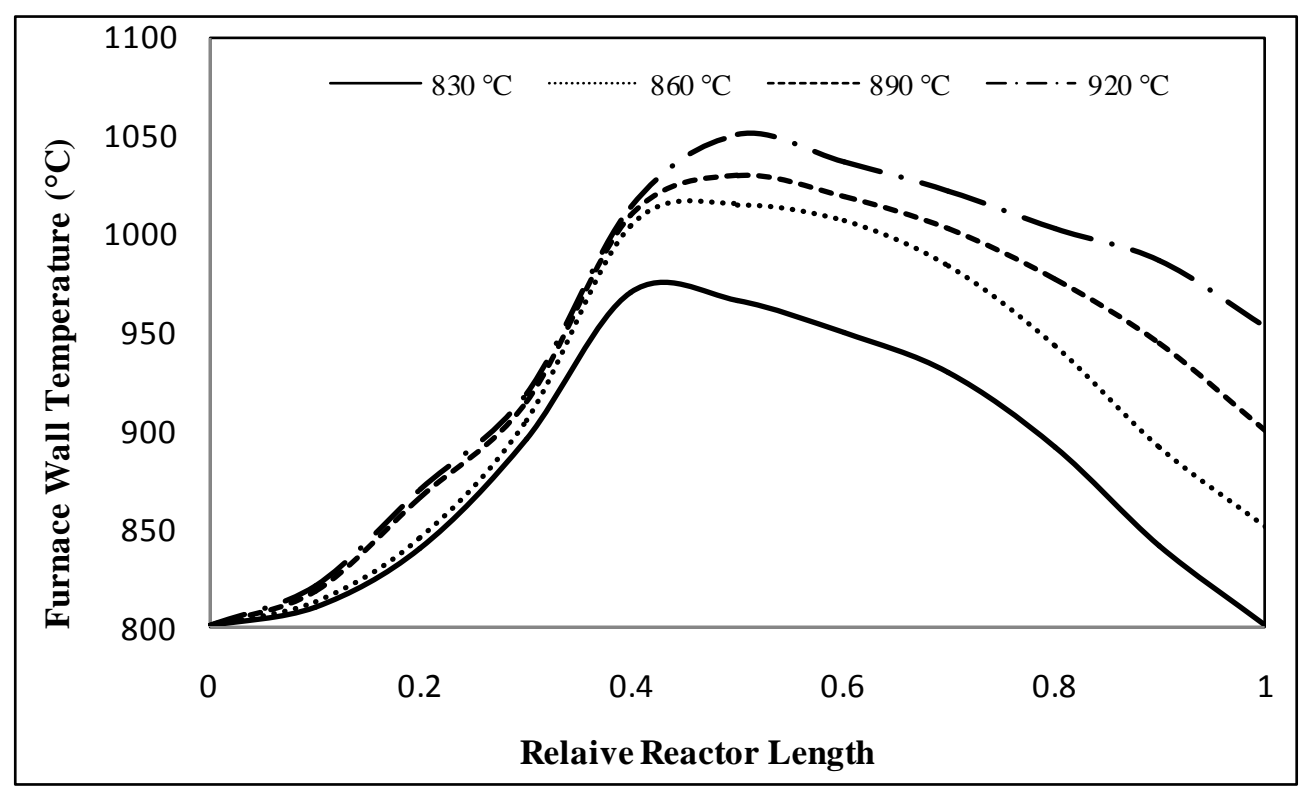

Figure (11): Effect of COTs on the furnace wall temperature behavior 


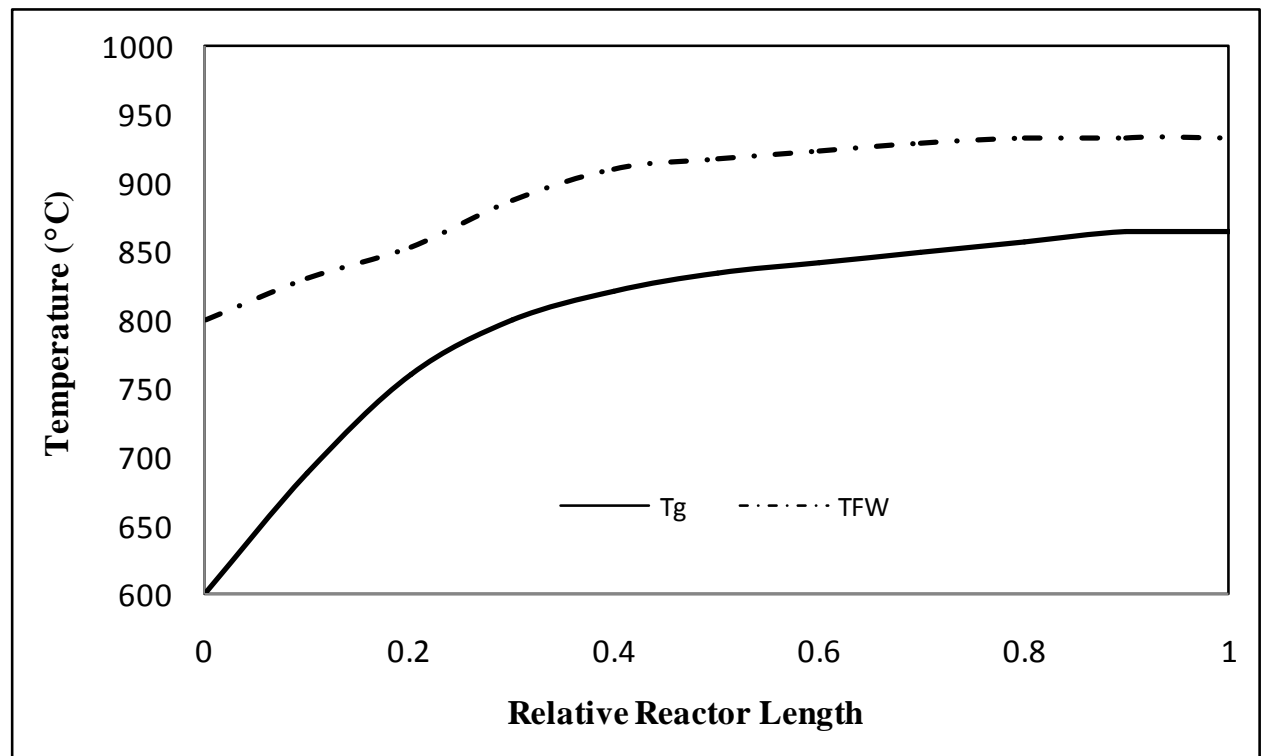

Figure (12): Optimum $\mathrm{T}_{\mathrm{g}}$ profiles with its corresponding $\mathrm{T}_{\mathrm{FW}}$ along the reactor length

\section{Nomenclature}

$\begin{array}{ll}A_{w} & \text { furnace wall area }\left(\mathrm{m}^{2}\right) \\ C_{i} & \text { concentration of component } i\left(\mathrm{~mol} / \mathrm{m}^{3}\right) \\ C_{p i} & \text { heat capacity of component } i(\mathrm{~J} / \mathrm{mol} . \mathrm{K}) \\ d r & \text { reactor diameter }(\mathrm{m}) \\ E_{i} & \text { activation energy, } \mathrm{J} / \mathrm{mol} \\ F_{i} & \text { molar flow rate of component } \mathrm{i}(\mathrm{mol} / \mathrm{s}) \\ F r & \text { friction function } \\ G & \text { total mass flux }\left(\mathrm{kg} / \mathrm{m}^{2} . \mathrm{s}\right) \\ h & \text { heat-transfer coefficient }\left(\mathrm{W} / \mathrm{m}^{2} . \mathrm{K}\right) \\ \Delta H_{j} & \text { heat of reaction } j(\mathrm{~J} / \mathrm{mol}) \\ L & \text { reactor length }(\mathrm{m}) \\ M_{i} & \text { molecular weight of component } i(\mathrm{~g} / \mathrm{mol}) \\ M_{m} & \text { molecular weight of mixture }(\mathrm{g} / \mathrm{mol}) \\ n_{d} & \text { frequency of decoking } \\ n_{d e} & \text { number of reactor shutdown } \\ N_{c} & \text { number of components } \\ N_{r} & \text { number of reactions } \\ P r & \text { Prandtl number } \\ P_{r H} & \text { heat price }(\$ / \mathrm{kJ}) \\ P_{r i} & \text { price of component } i(\$ / \mathrm{g}) \\ P_{t} & \text { total pressure }(\text { atm. abs }) \\ Q & \text { heat flux }\left(\mathrm{kJ} / \mathrm{m}^{2} . \mathrm{s}\right) \\ R & \text { gas constant }(\mathrm{J} / \mathrm{mol} . \mathrm{K}) \\ R_{b} & \text { radius of the bend }(\mathrm{m}) \\ R e & \text { Reynolds number } \\ r_{j} & \text { rate of reaction } j\left(\mathrm{~mol} / \mathrm{m}^{3} . \mathrm{s}\right) \\ & \end{array}$


$r_{c o} \quad$ average rate of coke formation $\left(\mathrm{mol} / \mathrm{m}^{3} . \mathrm{s}\right)$

$r_{c t} \quad$ average rate of coke formation for a specific temperature profile $\left(\mathrm{mol} / \mathrm{m}^{3} . \mathrm{s}\right)$

$r_{\text {ctot }} \quad$ rate of coke formation $\left(\mathrm{mol} / \mathrm{m}^{3} . \mathrm{s}\right)$

$S_{i j} \quad$ stoichiometric coefficient of component $i$ in reaction $j$

$T_{g} \quad$ gas temperature inside the reactor $(\mathrm{K})$

$T_{F W} \quad$ furnace wall temperature $(\mathrm{K})$

$T_{r} \quad$ reduced temperature $(\mathrm{K})$

$T_{W} \quad$ reactor wall temperature $(\mathrm{K})$

$t_{d} \quad$ decoking time (hr)

$t_{e} \quad$ production time between consecutive decoking processes $(\mathrm{hr})$

$t_{p} \quad$ yearly production time (hr)

$V_{c i} \quad$ critical volume of component $i\left(\mathrm{~cm}^{3} / \mathrm{mol}\right)$

$y_{i} \quad$ fraction of component $i$

$z \quad$ length coordinate $(\mathrm{m})$

$Z_{i} \quad$ compressibility factor

\section{Greek letters}

$\rho_{i} \quad$ density of component $i\left(\mathrm{~kg} / \mathrm{m}^{3}\right)$

$\alpha \quad$ cross sectional area $\left(\mathrm{m}^{2}\right)$

$\varphi \quad$ constant $(\mathrm{atm} / \mathrm{Pa})$

$\sigma \quad$ Stefan-Boltzmann constant

$\lambda_{i} \quad$ thermal conductivity on component $i(\mathrm{~W} / \mathrm{m} . \mathrm{K})$

$\mu_{i} \quad$ viscosity of component $i\left(\mathrm{~N} / \mathrm{m}^{2} . \mathrm{s}\right)$

$\omega \quad$ viscosity collision integral

\section{Superscripts}

* the target final value

\section{Subscripts}

$g \quad$ gas

$m \quad$ mixture

$w \quad$ wall

$F w \quad$ furnace wall 


\section{التصميم الأمثل لمفاعل التكسير الحراري الصناعي للنفثا}

$$
\begin{aligned}
& \text { أيسر طالب جار الله، اركان جاسم هادي، شيماء علي حميد } \\
& \text { مدرس، كلية الرندسة، جامعة تكربت }
\end{aligned}
$$

الخلاصة:

الدراسة المقدمة تتمل التصميم الأمنل للمفاعل الصناعي لعملية تكسير النفتا بالحرارة لغرض زيادة انتاجية الأثثلين والذي يعتبر واحد من أهم العمليات الصناعية الكيمياوية والفوائد المتوخاة نتيجة زيادة الإنتاجية والتي تؤدي بدورها لئية إلى زيادة الربحية.

تم استخدام عملية الاستمثال بهدف الوصول إلى أفضل موديل رياضي يمكن أن بطبق بدقة عالية في توصيف عمل المفاعل والوصول إلى التصميم الأمتل. المعالم الحركية المطورة والمستحصل عليها بالاعتماد على نتائج حقيقية

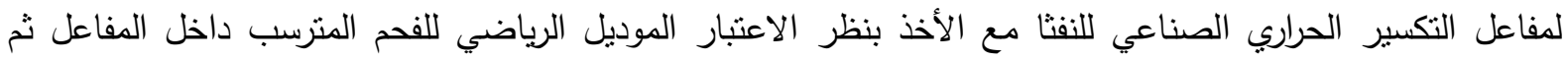
تطبيقها للتتبؤ بإنتاجية النواتج وسلوك درجة الحرارة المنلى على طول المفاعل لغرض الحصول على أعلى ربحية بحيث تلبي جميع شروط العملية. تأثز الظروف النتشيلية (درجة الحرارة, معدل الجريان , نسبة البخار إلى النفنا) على إنتاجية النواتج تم مناقشتها

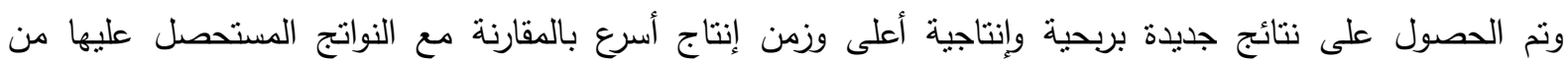

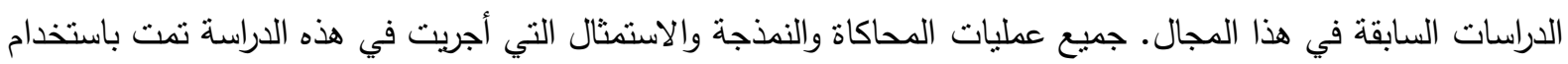

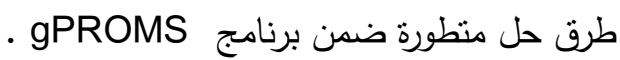
الكلمات الدالة: التكسير الحراري للنفتا ، انتاج الأثثلين , التحلل الحراري للنفتا. 